\title{
Suspended particulate matter status of urban area's in Mysore
}

\section{SREENIVASA AND G.V. VENKATARAMANA}

Article Chronicle :

Received:

25.04.2016;

Accepted :

30.05.2016
ABSTRACT : : The present study indicates the variation of SPM concentration of Mysore city during the year 2013 to 2015 at three sampling locations. During the study period the average values of SPM ranges from $37.0 \mu \mathrm{g} / \mathrm{m}^{3}$ to $62.25 \mu \mathrm{g} / \mathrm{m}^{3}$. In the year 2013 highest values of SPM was recorded in KSRTC bus station $\left(58.25 \mu \mathrm{g} / \mathrm{m}^{3}\right)$ followed by Irwin road $\left(56.50 \mu \mathrm{g} / \mathrm{m}^{3}{ }^{3}\right)$ and $\operatorname{KSPCB}\left(53.50 \mu \mathrm{g} / \mathrm{m}^{3}\right)$. During 2014 the average concentration of SPM found to be in the order of KSPCB $\left(62.25 \mu \mathrm{g} / \mathrm{m}^{3}\right), \operatorname{KSRTC}(59.0 \mu \mathrm{g} /$ $\mathrm{m}^{3}$ ) and Irwin road $\left(57.0 \mu \mathrm{g} / \mathrm{m}^{3}\right)$. At last in 2015 the highest average concentration of SPM values were recorded in KSRTC $\left(56.0 \mu \mathrm{g} / \mathrm{m}^{3}\right)$ and lowest values were recorded in $\mathrm{KSPCB}\left(37.00 \mu \mathrm{g} / \mathrm{m}^{3}\right)$.

HOW TO CITE THIS ARTICLE : Sreenivasa and Venkataramana, G.V. (2016). Suspended particulate matter status of urban area's in Mysore. Asian J. Environ. Sci., 11(1): 124-128, DOI: 10.15740/HAS/AJES/11.1/124128.

Key Words :

Suspended

particulate matter,

Monitoring, City

roads,

Concentration,

Environmental

quality, Air

pollutants 